\title{
Biosynthesis of gold nanoparticles (AuNPs) and the reducing agents in the process ${ }^{\diamond}$
}

\section{Biosíntesis de nanopartículas de oro (AuNPs) y los agentes reductores implicados en el proceso}

\author{
Blanca Estela Chávez Sandoval,*,^ Nallely Flores-Mendoza,** Auraamellaly Chávez- \\ Recio, ${ }^{* * *}$ José Abraham Balderas-López, ${ }^{* *}$ Francisco García-Franco****
}

\begin{abstract}
Metallic nanoparticles (NPs) are being used mainly because they have excellent physical, chemical and biological properties, intrinsic to their size, therefore there is a boom in the use of these nanoparticles in various fields and recently, due to the pandemic about coronavirus. Copper NPs began to be used for use in medical supplies such as face masks. NPs are normally obtained through inorganic synthesis, however, the methodologies used to obtain them are in general terms expensive and involve the use of hazardous chemicals, which has increased the development of sustainable and environmentally friendly alternatives, as one of the main objectives of nanotechnology. Considering that nanoparticle biosynthesis is of greatest importance since it allowed obtaining organic NPs through an environmentally friendly; quick and inexpensive.

In this work, the synthesis and characterization of AuNPs of six different plant extracts that in traditional medicine are used for respiratory diseases care, were performed. These NPs can be used in different fields; even they represent a good option to be added to medical supplies. As the AuNPs obtained from chamomile extract that turned out to be spherical, $20 \mathrm{~nm}$ in diameter, and well dispersed, these could be applied orally, as nanocapsules that are easily eliminated from the human body, or by aerosol, as a possible treatment for the pneumonia and SARS-CoV-2, in addition later for other nosocomial diseases. And to answer the question of what or which reducing agents are involved in the process? We proposed that, for biological synthesis, malic acid may be acting as a reducing agent and the amino group as a stabilizing agent, so we performed a synthesis with malic acid and obtained stable NPs. However, we do not dismiss other metabolites enzymes and/or proteins that could be involved in the process.
\end{abstract}

KEYWORDS: gold nanoparticles, biosynthesis, malic acid, Syzygium aromaticum, Olea europaea, Amphipterygium adstringens, Morinda citrifolia, Lobaria pulmonaria, Matricaria chamomilla.

RESUMEN: Las nanopartículas metálicas (NPs) se utilizan debido a sus excelentes propiedades fisicas, químicas y biológicas, intrínsecas a su tamaño, por lo que existe un auge en el uso de estas en diversos campos y, recientemente, debido a la pandemia por el coronavirus. Las NP de

Received: July 10, 2020.

Accepted: November 5, 2020.

${ }^{\circ}$ Acknowledgements: BECS thanks Conacyt (CVU 249131); ACR thanks AMEX-TNN (www. amextnn.org) for the scholarship granted to carry out this study and the medical undergraduate intern; All authors acknowledgements to Patricia Castillo from UAM-Iztapalapa for her support in the characterization of AuNPs in the TEM, and Dra. Marina Olivia Franco for her support to characterization of UV-Vis in UPIBI-IPN.

* Universidad Autónoma Metropolitana, Unidad Cuajimalpa.

** Instituto Politécnico Nacional, Unidad Profesional Interdisciplinaria en Biotecnología.

*** Universidad Nacional Autónoma de México, Facultad de Estudios Superiores, Iztacala.

****Universidad Autónoma Metropolitana, Unidad Azcapotzalco.

- Correspondence author: blanchavez29@gmail.com 
cobre comenzaron a incorporarse en suministros médicos, como máscaras faciales o cubrebocas. Las NP normalmente se obtienen mediante síntesis inorgánica, no obstante, las metodologías que se utilizan para su obtención son en términos generales costosas e implican el uso de químicos peligrosos, lo cual ha incrementado el desarrollo de alternativas sostenibles y amigables con el medio ambiente, como uno de los principales objetivos de la nanotecnología. En este trabajo, se realizó la síntesis y caracterización de AuNPs de seis extractos de plantas que en la medicina tradicional se utilizan para el cuidado de enfermedades respiratorias, considerando que la biosíntesis de nanopartículas es de gran importancia al permitir obtener NP estables a través de un método amigable con el ambiente, rápido y económico. Las NP obtenidas se pueden utilizar en diferentes campos, representan incluso una buena opción para agregarse a los suministros médicos, como las AuNPs obtenidas a partir del extracto de manzanilla que resultaron ser esféricas, de $20 \mathrm{~nm}$, y bien dispersas, estas podrían ser aplicadas por vía oral, como nanocápsulas que se eliminen fácilmente del cuerpo humano, o mediante aerosol, como posible tratamiento primero para la neumonía y el SARS-CoV-2, y, posteriormente, para otras enfermedades nosocomiales. Y para responder a la pregunta sobre ¿qué agentes reductores intervienen en el proceso de biosíntesis de AuNPs?, proponemos que el ácido málico puede estar actuando como agente reductor, y el grupo amino como agente estabilizador; de este modo, realizamos una síntesis con ácido málico y obtuvimos NP estables. Sin embargo, no descartamos otros metabolitos, enzimas y/o proteínas que podrían estar involucradas.

PALABRAS CLAVE: nanopartículas de oro, biosintesis, ácido málico, Syzygium aromaticum, Olea europaea, Amphipterygium adstringens, Morinda citrifolia, Lobaria pulmonaria, Matricaria chamomilla.

\section{Introduction}

Research into the behaviour of matter on the nanometric scale has opened a promising prospect of new knowledge and applications. The physical properties of nanometric materials are very different from those seen in a macroscopic-sized solid with the same chemical composition.

At this time, experimental techniques are beginning to be used on a regular basis that make it possible to manufacture, characterize and manipulate nanometric materials for use in various fields such as genomics, medical diagnosis, pharmacogenetics, pathology, criminology, food safety, environmental monitoring, among others (Chávez-Sandoval et al., 2020; Fujimori et al., 2012).

Regarding the properties of nanoparticles (NPs), in particular the optical properties depend fundamentally on the size, shape and spatial distribution of these in the sample, which can be sphere, bar, cube, triangle, between others and these characteristics are of great relevance for its correct use (Chávez-Sandoval et al., 2015; Abrica-González et al., 2018).

Noble metal NPs are widely used in the medical field due to the low toxicity and biocompatibility of these metals, however the toxicity of NPs is not yet well demonstrated; therefore, biologically synthesizing gold nanoparticles (AuNPs) is an alternative procedure to chemical synthesis, it is simple, inexpensive and less harmful to the environment. Furthermore, the use of plant extracts for the synthesis of nanomaterials has not been fully explored and represents a good alternative since stable NPs of different size and shape are obtained (Rico-Moctezuma et al., 2010; Panda and Deepa, 2011; ChávezSandoval et al., 2016). 
In this work, the synthesis and characterization of gold nanoparticles (AuNPs) was performed using plant extracts as a reducing agent, the plants were: clove (Syzygium aromaticum); chamomile (Matricaria chamomilla); cuachalalate (Amphipterygium adstringens); pulmonaria (Lobaria pulmonaria); noni (Morinda citrifolia) and olive leaves (Olea europaea), due to their traditional use in the treatment of common cold, fever, influenza virus infections and pneumonia, among others (Liu et al., 2017). Consequently, the NPs obtained could be used to guarantee public health if used as sanitizing agents in medical supplies, considering that the world is suffering from the coronavirus pandemic and that we will surely continue to face other epidemics and/ or pandemics.

Finally, a synthesis of AuNPs was carried out using malic acid because it is one of the most abundant acids in nature, it is found in fruits and vegetables, it is easily metabolized and it is essential for the Krebs cycle, since mitochondrial-malate metabolism modulates ADP-glucose pyrophosphorylase activity and redox status of plastids (Shitan and Yasaki, 2013; Shitan et al., 2013). Despite this, it is possible that other metabolites, enzymes and/or proteins are also involved in the process.

\section{Materials and methods}

\section{Reagents and solutions}

All reagents used were analytical grade and all solutions were prepared using double deionized water (Milli-Q, $18 \mathrm{MW} \mathrm{cm}$ ) from a Millipore purification system. Hydrogen tetrachloroaurate (III) trihydrate ( $\mathrm{HAuCl} 4 \cdot 3 \mathrm{H} 2 \mathrm{O}, 99.99 \%)$ (520918) were purchased from Sigma-Aldrich and Malic acid (2-Amino-3-hydroxysuccinic acid, C4H7NO5, 97\%), from Merck. Formvar 15/95 resin, 75 mesh copper grids (GilderGrids $\mathrm{Cu}$ ) and mica muscovita $\mathrm{V}$-1 quality were purchased from Electron Microscopy Sciences.

\section{AuNPs biosynthesis}

The method described by Chávez-Sandoval et al. (2016) was used, whit some modifications as described below.

Obtaining natural extracts:

Aqueous extracts were obtained from the chosen biological material (table 1). $5 \mathrm{~g}$ of biological material (fresh plant if that are possible) were weighed and boiled in $10 \mathrm{~mL}$ of distilled water, the resulting extract was boiled again adding another $10 \mathrm{~mL}$ of distilled water and another $5 \mathrm{~g}$ of plant, this in order to promote concentration. All the extracts were prepared the same day that the synthesis of AuNPs was performed to avoid interferences in the result because of oxidation and transformation of the secondary metabolites present in the extracts. The $\mathrm{pH}$ of each extract was also measured. The $\mathrm{pH}$ of the extracts was assessed using a pH meter brand Mettler Toledo MPC 227. Biosynthesis was carried out in triplicate to ensure reproducibility. 
Mundo Nano | RESEARCH ARTICLES | www.mundonano.unam.mx

14(27), 1e-11e, July-December 2021 | https://doi.org/10.22201/ceiich.24485691e.2021.27.69658

Blanca Estela Chávez Sandoval, Nallely Flores-Mendoza, Auraamellaly Chávez-Recio, José Abraham Balderas-López, Francisco García-Franco

The AuNPs obtained leave to cool at $25^{\circ} \mathrm{C}$ with stirring and they were packaged in sterile bottles and then stored at $4{ }^{\circ} \mathrm{C}$ for their preservation and posterior characterization by UV-Vis spectroscopy and transmission electron microscopy (TEM) to determinate size and shape. Spectroscopy UV-Vis:

UV-Vis spectroscopic measurements were conducted using a Perkin Elmer

Table 1. Description, main characteristics, and medical reports of the biological material used to biosynthesize AuNPs.

\begin{tabular}{|c|c|c|c|}
\hline Name & Description & Uses and atributes & Medical Reports \\
\hline $\begin{array}{l}\text { Common name: Clove } \\
\text { Scientific name: } \\
\text { Syzigium aromaticum }\end{array}$ & $\begin{array}{l}\text { From Indonesia, they are the buds of } \\
\text { the tree's flowers which are removed } \\
\text { and dried in the sun or in hot air } \\
\text { chambers until they have lost two } \\
\text { thirds of their original weight. It gets } \\
\text { its name due to the shape that a nail } \\
\text { simulates or a chalice shape when the } \\
\text { flower leaves are folded, just before } \\
\text { flowering. }\end{array}$ & $\begin{array}{l}\text { It is a very aromatic spice. It has been } \\
\text { described as having antiseptic, } \\
\text { healing, analgesic and stimulating } \\
\text { properties of appetite and digestion }\end{array}$ & $\begin{array}{l}\text { It has been reported to be } \\
\text { rich in essential oils and } \\
\text { they have shown that when } \\
\text { combined with cinnamon } \\
\text { essential oils it has an } \\
\text { inhibition of the growth of } \\
\text { gram negative bacteria such } \\
\text { as a Pseudomona aeruginosa } \\
\text { (Aglaoglu et al., 2007; Celis, } \\
\text { 2010; Liu et al., 2017), }\end{array}$ \\
\hline $\begin{array}{l}\text { Common name: Pulmonary } \\
\text { Scientific name: } \\
\text { Lobaria pulmonaria }\end{array}$ & $\begin{array}{l}\text { From Europe, it is a foliar lichen that } \\
\text { spread on the ground, generally at the } \\
\text { foot of trees or on the trunk, forming } \\
\text { sheets. It has large lobed leaves, } \\
\text { which are whitish in wet weather and } \\
\text { turn brown in dry weather. }\end{array}$ & $\begin{array}{l}\text { It has a bitter astringent taste due to } \\
\text { stictinic acid which makes it useful in } \\
\text { medicine and coloring substances } \\
\text { used in the preparation of litmus } \\
\text { solutions. }\end{array}$ & $\begin{array}{l}\text { It is used for the treatment } \\
\text { of cough, common fever and } \\
\text { common cold, due to its } \\
\text { expectorant and mucolytic } \\
\text { effect (Lerchundi, 2006). }\end{array}$ \\
\hline $\begin{array}{l}\text { Common name: Olive le } \\
\text { Scientific name: } \\
\text { Olea europaea }\end{array}$ & $\begin{array}{l}\text { From Europe, these leaves come from } \\
\text { the olive tree or olives and are } \\
\text { between } 3 \text { and } 4 \mathrm{~cm} \text {. They are green } \\
\text { and, on the underside, they are lighter } \\
\text { in tone. They are connected by small } \\
\text { branches to the central branch that } \\
\text { connects to the tree trunk. }\end{array}$ & $\begin{array}{l}\text { Antioxidant effect, anti-sclerotic, } \\
\text { antimicrobial, apoptosis-inducing } \\
\text { activity due to the presence of } \\
\text { Hydroxytyrosol (De la Fuente } \text { et al., } \\
\text { 2004). }\end{array}$ & $\begin{array}{l}\text { Hydroxytyrosol has been } \\
\text { shown to be a good } \\
\text { candidate for use as an } \\
\text { antimicrobial agent against } \\
\text { Haemophilus influenzae, } \\
\text { Salmonella sp, Vibrio } \\
\text { parahaemolyticus and } \\
\text { Staphilococcus aereus in } \\
\text { humans (De la Fuente et al., } \\
\text { 2004). }\end{array}$ \\
\hline $\begin{array}{l}\text { Common name: Chamomille } \\
\text { Scientific name: } \\
\text { Matricaria chamomilla }\end{array}$ & $\begin{array}{l}\text { From Europe, it is a plant that reaches } \\
\text { a height of } 40 \mathrm{~cm} \text {, is annual branched, } \\
\text { with a characteristic aroma and very } \\
\text { aromatic, with a straight stem. It is } \\
\text { characterized by its flower that consist } \\
\text { of a yellow center and white petals. }\end{array}$ & $\begin{array}{l}\text { It has anti-inflammatory, } \\
\text { antispasmodic, choleretic, as well as } \\
\text { sedative and relaxant effects, in } \\
\text { addition to antiseptics due to its } \\
\text { content in essential oils, flavonoids } \\
\text { and other active ingredients. }\end{array}$ & $\begin{array}{l}\text { It has been reported as a } \\
\text { treatment for eye infections, } \\
\text { help against common cold, } \\
\text { among others (Morales y } \\
\text { Pardo de Santayana, 2006). }\end{array}$ \\
\hline $\begin{array}{l}\text { Common name: Noni } \\
\text { Scientific name: } \\
\text { Morinda citrifolia }\end{array}$ & $\begin{array}{l}\text { From Southeast Asia, is an irregular, } \\
\text { ovoid and large fruit with a transparent, } \\
\text { gelatinous pulp whose seeds are found } \\
\text { in said pulp and are small and glossy } \\
\text { with a dark brown color. It comes from a } \\
\text { small tree up to } 4 \text { meters high; its flowers } \\
\text { appear in groups and are white (Rojas, } \\
\text { 2007). }\end{array}$ & $\begin{array}{l}\text { Leaves, flowers, seeds and root, it is } \\
\text { found today in many natural products } \\
\text { for the treatment of different } \\
\text { conditions such as allergies, arthritis, } \\
\text { asthma, cataracts, diabetes, colitis, } \\
\text { stress, gastric ulcers, varicose veins, } \\
\text { heart problems, pressure and } \\
\text { antiseptic properties are attributed to } \\
\text { this fruit. }\end{array}$ & $\begin{array}{l}\text { It has been reported that } \\
\text { some compounds from the } \\
\text { fruit and the root have been } \\
\text { shown to have an inhibitory } \\
\text { effect on strains of } \\
\text { Pseudomona aeruginosa, } \\
\text { Proteus morganii, } \\
\text { Staphylococcus aereus, } \\
\text { Bacillus subtilis, Escherichia } \\
\text { Coli and Helicobacter pylori } \\
\text { (Torres and Toranzo, 2006; } \\
\text { Rojas, 2007). }\end{array}$ \\
\hline $\begin{array}{l}\text { Common name: Cuachalalate } \\
\text { Scientific name: } \\
\text { Amphipterygium adstringens }\end{array}$ & $\begin{array}{l}\text { From México, bark obtained from the } \\
\text { tree of the same name that comes } \\
\text { from the Nahuatl Cuauchachalatli, } \\
\text { which means chachalaca tree. This } \\
\text { bark is hard and thick, smooth looking } \\
\text { with some bumps. If the extraction of } \\
\text { the bark of the tree in not carried out } \\
\text { properly, it dies because it cannot } \\
\text { regenerated it, that's why it is in } \\
\text { danger of extinction. }\end{array}$ & $\begin{array}{l}\text { It is used in the treatment of gastritis; } \\
\text { it as also used to treat peptic ulcers. } \\
\text { More than } 30 \text { medicinal uses have } \\
\text { been found as an antitumor agent, } \\
\text { hypocholesterolemiant, malaria, } \\
\text { intermittent fevers, astrigent, } \\
\text { anti-inflammatory, amog others. }\end{array}$ & $\begin{array}{l}\text { The extract of cuachalalate } \\
\text { has been shown to have an } \\
\text { inhibitory effect against } \\
\text { Pseudomona aeruginosa } \\
\text { and Helicobacter pylori } \\
\text { (Castillo-Juárez et al., 2013; } \\
\text { Rodríguez-García et al., 2015). }\end{array}$ \\
\hline
\end{tabular}

Source: Authors'elaboration. 
Lambda 35 spectrophotometer at room temperature from 400 to $700 \mathrm{~nm}$ in UPIBI-IPN, Mexico City.

TEM characterization

We used a HRTEM Jeol 2100F; $160-200 \mathrm{kV} \mathrm{FE;} 0.23 \mathrm{~nm}$ resolution; $\times 10-8 \mathrm{~Pa}$ order Pressure. From Central Laboratory of Electronic Microscopy at UAMIztapalapa, Mexico City.

\section{Results and discussion}

The results obtained are consistent with that reported by Rico-Moctezuma et al. (2010); Panda and Deepa (2011), Chávez-Sandoval et al. (2020 y 2016) and Khan et al. (2019), among others, on AuNPs biosynthesis.

\section{AuNPs biosynthesis}

\section{Natural extracts}

Table 2 shows the $\mathrm{pH}$ of the extracts obtained, since Chávez-Sandoval et al. (2020), reports that $\mathrm{pH}$ is one of the important factors during biosynthesis to control the size and shape of NPs. Note that most of the extracts were acidic in a $\mathrm{pH}$ range of 4 to 4.5 , except for the chamomile extract, which was neutral with a $\mathrm{pH}$ of 7.3 .

Figure 1 shows the natural extract and AuNPs obtained of each plant, on the left the extract is observed ( $A, C, E, G, I, K)$ and on the right the biosynthesized nanoparticles (B, D, F, H, J, L).

Also, we obtained AuNPs of malic acid in a purple colloid (figure 2), with a maximum wavelength of approximately $560 \mathrm{~nm}$ (figure 4) was corroborated, indicating that they are larger than $30 \mathrm{~nm}$ or that they are aggregated. UV-Vis spectroscopy

A sweep of 400 to $700 \mathrm{~nm}$ was performed to determine the maximum wavelength at which each AuNP absorbs. Figure 3 shows these results, and in figure 4 the UV-Vis spectroscopy of AuNPs obtained with malic acid.

Table 2. pH of the extracts of plants used as reducing agent.

\begin{tabular}{c|c}
\hline Extract & $\mathrm{pH}$ \\
\hline Clove & 4.1 \\
\hline Chamomile & 7.3 \\
\hline Noni & 4.0 \\
\hline Pulmonary & 4.4 \\
\hline Cuachalalate & 4.0 \\
\hline Olive leaves & 4.5 \\
\hline
\end{tabular}

Source: Authors'elaboration. 
Mundo Nano | RESEARCH ARTICLES | www.mundonano.unam.mx

14(27), 1e-11e, July-December 2021 | https://doi.org/10.22201/ceiich.24485691e.2021.27.69658

Blanca Estela Chávez Sandoval, Nallely Flores-Mendoza, Auraamellaly Chávez-Recio, José Abraham Balderas-López, Francisco García-Franco

Figure 1. A-B extract and AuNPs of olive leaves, C-D extract and AuNPs of cuachalalate, E-F extract and AuNPs of pulmonary, G-H extract and AuNPs of noni, I-J extract and AuNPs of chamomile and K-L extract and AuNPs of clove.

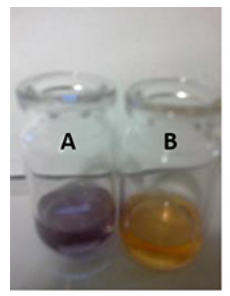

Olive leaves

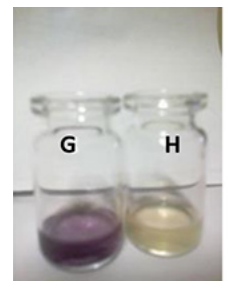

Noni

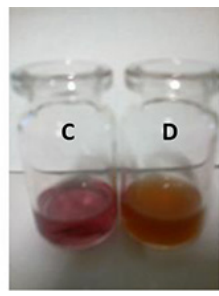

Cuachalalate

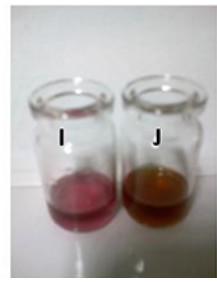

Chamomile

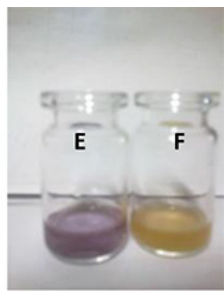

Pulmonary

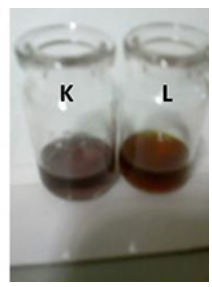

Clove

Source: Authors'elaboration.

\section{TEM characterization}

Once it was confirmed by UV-Vis that we obtained AuNPs, the samples were delivered to the UAM-Iztapalapa microscopy service. Figure 5 shows the results.

TEM images of AuNPs obtained with malic acid are in process, however, due to the coronavirus pandemic, we do not know when they will be available. To fully observe the results obtained in table 3 , a comparison of the $\mathrm{pH}$, wavelength, size and shape of the biosynthesized AuNPs is observed. Only chamomile AuNPs present a maximum absorbance at $528 \mathrm{~nm}$ and was homogeneous, note that the $\mathrm{pH}$ of the extract used as reducing agent was 7.3.

Figura 2. AuNPs of malic acid in a purple colloid.

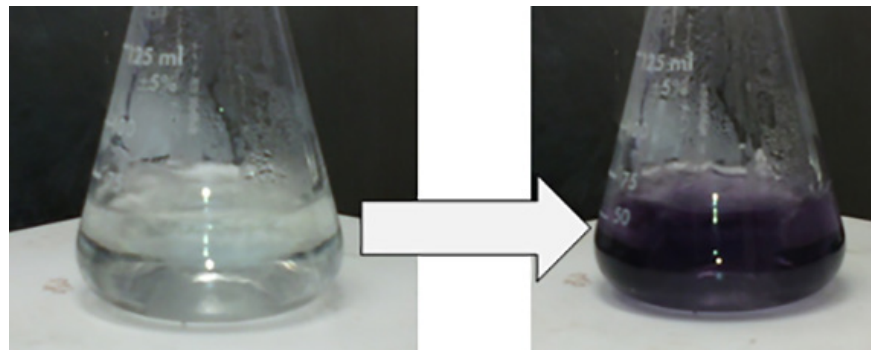

A. Malic acid.
B. AuNPs obtained

Source: Authors'elaboration. 
Figure 3. UV-Vis spectroscopy of AuNPs obtained.

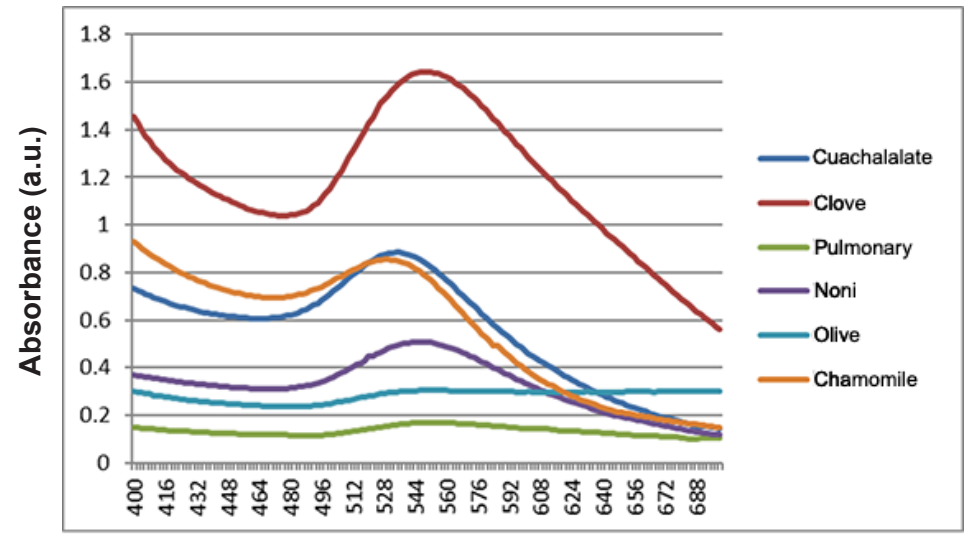

$\lambda \mathrm{nm}$

Source: Authors'elaboration.

Figure 4. UV-Vis absorption spectrum of AuNPs obtained using malic acid as a reducing agent.

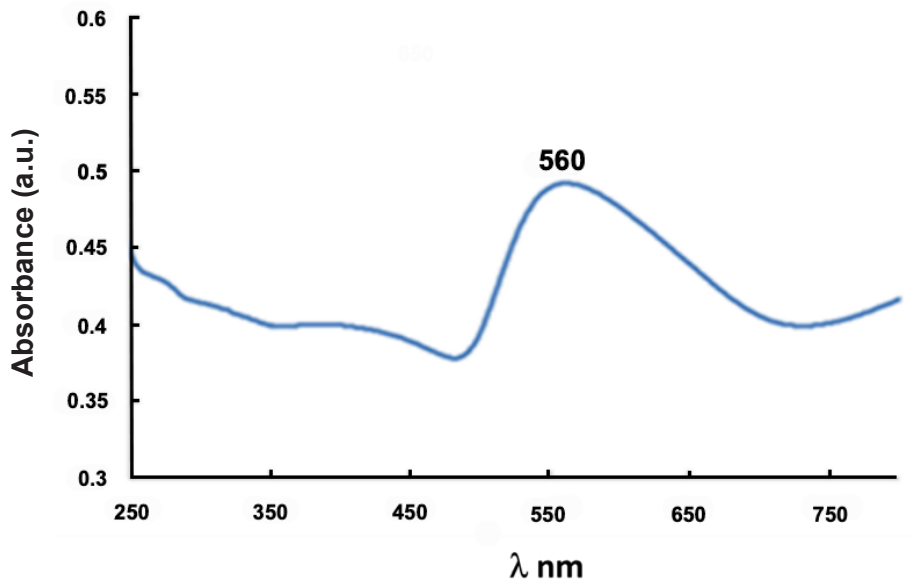

Source: Authors'elaboration.

Uv-Vis spectroscopy shown that malic acid AuNPs have a maximum absorbance of $560 \mathrm{~nm}$, so we would expect heterogeneous AuNPs of 50 to $100 \mathrm{~nm}$ in diameter like the pulmonary or olive leaves AuNPs, that present a maximum absorbance at $554 \mathrm{~nm}$ and $552 \mathrm{~nm}$, respectively. The clove, cuachalalate and noni AuNPs are approximately $20 \mathrm{~nm}$ in size, however they are observed aggregated and heterogeneous by TEM. Perhaps, because the $\mathrm{pH}$ of the extract used as a reducing agent it was acidic, hovering around a $\mathrm{pH}$ of 4. 
Mundo Nano | RESEARCH ARTICLES | www.mundonano.unam.mx

14(27), 1e-11e, July-December 2021 | https:// doi.org/10.22201/ceiich.24485691e.2021.27.69658

Blanca Estela Chávez Sandoval, Nallely Flores-Mendoza, Auraamellaly Chávez-Recio, José Abraham Balderas-López, Francisco García-Franco

Figure 5. TEM images of the AuNPs obtained, A-B clove, C-D chamomile, E-F noni, G-H pulmonary, I-J cuachalalate, $\mathrm{K}$-L olive leaves.
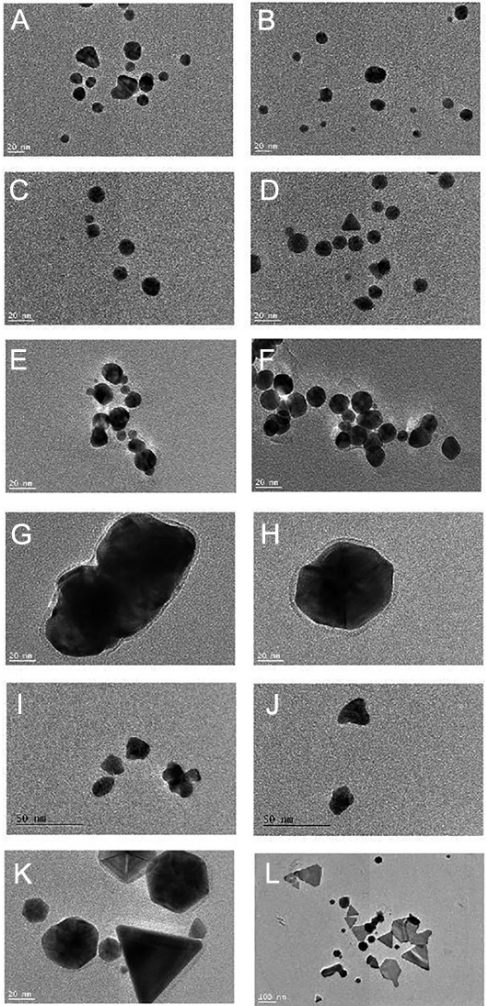

Source: Authors'elaboration.

Table 3. Extract, pH, maximum wavelength $(\lambda)$, diameter $(\varnothing)$ and morphology of the AuNPs obtained.

\begin{tabular}{c|c|c|c|c}
\hline Extract & $\mathrm{pH}$ & $(\lambda)$ & $(\phi) \mathrm{nm}$ & Morphology \\
\hline Clove & 4.1 & 550 & 20 & $\begin{array}{c}\text { Heterogeneous, spherical } \\
\text { and triangles }\end{array}$ \\
\hline Chamomile & 7.3 & 528 & 20 & Homogeneous, spherical \\
\hline Pulmonary & 4.0 & 546 & 20 & $\begin{array}{c}\text { Heterogeneous, aggregated, } \\
\text { mostly spherical }\end{array}$ \\
\hline Cuachalalate & 4.0 & 554 & $50-100$ & $\begin{array}{c}\text { Heterogeneous, aggregated, } \\
\text { mostly spherical }\end{array}$ \\
\hline Olive leaves & 4.5 & 552 & 100 & $\begin{array}{c}\text { Heterogeneous, mostly } \\
\text { spherical }\end{array}$ \\
\hline
\end{tabular}

Source: Authors'elaboration. 
Furthermore, it is observed that the chamomile AuNPs are homogeneous and mostly spherical because the $\mathrm{pH}$ of the extract with which they were synthesized was neutral ( $\mathrm{pH} 7$ ) and as reported by Chávez-Sandoval et al. (2020) in the biosynthesis is it is crucial that the $\mathrm{pH}$ is neutral or close to neutrality to obtain homogeneous nanoparticles in size and shape.

These biosynthesis results are consistent with that reported by ChávezSandoval et al. (2016), where they synthesized AuNPs from extracts of cactus (Opuntia sp.), onion (Allum sp.), pear (Pyrus sp.), coffee (Coffea sp.) and laurel (Laurus sp.); Panda and Deepa (2011), in their review on the biosynthesis of gold nanoparticles from microorganisms, plants, and other biological sources; or Khan et al. (2019) at a review about the fabrication strategies for gold nanoparticles via plant-based routes and highlights the diversity of the applications of these materials in bio-nanotechnology.

\section{Conclusions}

Stable gold nanoparticles (AuNPs) were obtained from the extracts of clove (Syzygium aromaticum); chamomile (Matricaria chamomilla); noni (Morinda citrifolia); pulmonary (Lobaria pulmonaria); cuachalalate (Amphipterygium adstringens) and olive leaves (Olea europea), AuNPs were also obtained stable AuNPs from malic acid, so it is corroborated that this metabolite is involved in the reduction of gold ions during biosynthesis.

Finally, homogeneous, spherical and of approximately $20 \mathrm{~nm}$ AuNPs such as those of chamomile (Matricaria chamomilla) can also be used to targeted drug delivery or develop biosensors and accelerate the detection of pathogenic microorganisms with these devices.

\section{Recommendations}

AuNPs obtained through biosynthesis could be used as sanitizing agents in medical implements such as gloves or face masks, mainly because the coronavirus pandemic has demonstrated the urgency of having these medical supplies, among others, such as hospital sheets or towels and clothing bedding in hotels, even in non-epidemic or pandemic conditions, mainly because if they are produced on a large scale, they could become cheap and because of their low toxicity.

\section{Perspectives}

The support of companies will be sought to develop the applications of these AuNPs as sanitizers and we will be carried out sensitivity tests to Pseudomona aeruginosa with different concentrations of AuNPs to be applied orally, like nanocapsules that are easily eliminated from the human body, or by spray as a possible treatment for pneumonia first and then for other nosocomial diseases (Kim et al., 2010; Hu et al., 2020). 


\section{References}

Abrica-González, P., Zamora-Justo, J. A., Chávez-Sandoval, B. E., Vázquez-Martínez, G. R., Balderas-López, J. A. (2018), Measurement of the optical properties of gold colloids by photoacoustic spectroscopy. International Journal of Thermophysics, ICPPP 19. https://doi.org/10.1007/s10765-018-2412-1

Agaoglu, S., Dostbil, S. and Alemdar, S. (2007). Antimicrobial activity of some spices used in the meat industry. Bull Vet Inst Pulawy, 51: 53-57.

Castillo-Juárez, I., García-Contreras, R., Velázquez-Guadarrama, N., Soto-Hernández, M., Martínez-Vázquez, M. (2013). Amphypterygium adstringens anacardic acid mixture inhibits quorum sensing-controlled virulence factors of Chromobacterium violaceum and Pseudomonas aeruginosa. Arch Med Res. 44(7): 488-94. https://doi.org/10.1016/j.arcmed.2013.10.004

Celis, L. (2010). Usos medicinales del clavo de olor Syzygium aromaticum (L.) (Merr. et Perry). México: Tlahui. Medicina tradicional mexicana.

Chávez-Sandoval, B. E., Balderas-López, J. A., Padilla-Bernal, G., Moreno-Rivera, M. L., Franco-Hernández, M. O., Martínez-Jiménez, A. and García-Franco, F. (2015). Photopyroelectric techniques for thermo-optical characterization of gold nano-particles. Journal of Physics: Conference Series, 582: 012027, IOP Science. https://doi.org/10.1088/1742-6596/582/1/012027

Chávez-Sandoval, B. E., Ibáñez-Hernández, M. A. A., García-Franco, F., GalindoPérez, E. J., Abrica-Gónzalez, P., Martínez-Jiménez, A. Balderas-López, J. A. (2016). Biological synthesis and characterization of gold nanoparticles (AuNPs), using plant extracts. Journal of Nanomaterials \& Molecular Nanotechnology, 5(4). http://dx.doi.org/10.4172/2324-8777.1000192

Chávez-Sandoval, B. E., Balderas-López, J. A., García-Franco, F., Galindo Pérez, E. J., Martínez-Jiménez, A., Ibáñez-Hernández, M. A. A. (2020). The role of pH in the synthesis, distribution and potential applications of gold nanoparticles. International Journal of Biomedical Nanoscience and Nanotechnology, 4(1/2): 120-138. https://doi.org/10.1504/IJBNN.2020.10029083

De la Fuente, P., Chamorro, P., Moreno, M. Poza, M. (2004). Propiedades antioxidantes del hidroxitirosol procedente de la hoja de olivo (Olea europea). Revista de Fitoterapia, 4(2): 139-147.

Fujimori, Y., Sato, T., Hayata, T., Nagao, T., Nakayama, M., Nakayama, T., Sugamata, R., Suzukic, K. (2012). Novel antiviral characteristics of nanosized copper (I) Iodide particles showing inactivation activity against 2009 pandemic H1N1 Influenza virus. Applied and Environmental Microbiology, 78(4): 951-955. https://doi.org/10.1128/AEM.06284-11

$\mathrm{Hu}, \mathrm{T}$., Frieman, M., Wolfram, J. (2020). Insights from nanomedicine into chloroquine efficacy against Covid-19. Comment. https://doi.org/10.1038/s41565-020-0674-9

Khan, T., Ullah, N., Khan, M., Mashwani, Z., Nadhman, A. (2019). Plant-based gold nanoparticles; a comprehensive review of the decade-long research on synthesis, mechanistic aspects and diverse applications. Adv Colloid Interface Sci. 272: 102017. https://doi.org/10.1016/j.cis.2019.102017 
Kim, B., Rutka, J., Chan, W. (2010). The new England journal of medicine. 16; 363(25): 2434-43. https://doi.org/10.1056/NEJMra0912273

Liu, Q., Meng, X., Li, Y., Zhao, C., Tang, G. and Li, H. (2017) Antibacterial and antifungal activities of spices. Int J Mol Sci. 18(6). https://doi.org/10.3390/ijms18061283

Lerchundi, A. M. (2006). Líquenes medicamentosos. http://www.acfah.org/privado/ apuntes/1-liq-med.pdf [24th April 2020].

Morales, R. and Pardo de Santayana, M. (2006). Manzanillas ibéricas: historia y usos tradicionales. Revista de Fitoterapia, 6(2):143-153.

Panda, T. and Deepa, K. (2011). Biosynthesis of gold nanoparticles. J Nanosci Nanotechnol. 11(12): 10279-94. https://doi.org/10.1166/jnn.2011.5021

Rico-Moctezuma, A., Vilchis-Néstor, A., Sánchez-Mendieta, V. (2010). Biosíntesis de nanopartículas de oro mediante el extracto de Opuntia ficus-indica. Superficies y Vacío, 23(S): 94-97. SV23S9410.pdf

Rodríguez-García, A., Peixoto, I. T. A.,Verde-Star, M. J., De la Torre-Zavala, S., AvilesArnaut, H. and Ruiz, A. L. T. G. (2015). In vitro antimicrobial and antiproliferative activity of Amphipterygium adstringens. Hindawi Publishing Corporation, Evidence-Based Complementary and Alternative Medicine. Article ID 175497, P.7. https://doi.org/10.1155/2015/175497

Rojas Rodríguez, F. (2007). Árboles que curan: el noni. Kurú. Revista Forestal, 4(10): 4. Costa Rica.

Shitan, N. and Yazaki, K. (2013). New insights into the transport mechanisms in plant vacuoles. Int Rev Cell Mol Biol, 305: 383-433. https://doi.org/10.1016/ B978-0-12-407695-2.00009-3

Shitan, N., Dalmas, F., Dan, K., Kato, N., Ueda, K., Sato, F., Forestier, C., Yasaki, K. (2013). Characterization of Coptis japónica CjABCB2, an ATP-binding cassette protein involved in alkaloid transport. Phytochemistry, 91: 109-116.

https://doi.org/10.1016/j.phytochem.2012.02.012

Torres Peydró, A., Toranzo Reyes, A. (2006). Morinda citrifolia (Tahitian Noni). History, current studies about its medical use. Review. Departamento de Estomatología Infantil. Unidad Docente de Estomatología. Universidad Médica Mariana Grajales Coello. Holguín, Cuba. 